UDC 339.5

\title{
Trade in services of member states of the Eurasian Economic Union
}

\author{
Kuanysh N. Yelikbaev \\ Eurasian Economic Commission \\ 3/5 Smolensky Blvd., bldg. 1, Moscow 119121, Russian Federation
}

\begin{abstract}
The Treaty on the Eurasian Economic Union, which became effective since January 1,2015, establishes the principles and the purposes of integration consolidation and also provides free movement of goods, services, the capital and labor power in the internal market and coordinated, approved, uniform to policy in the designated spheres of economic activity. In the article, the analysis of foreign and internal trade in services in the Eurasian Economic Union is given. The structure and import volume and export of member countries of EAEU are considered. The relevance of a subject is connected with the fact that free movement of services is one of the main directions of integration within the Eurasian Economic Union. As a result of the conducted research, the corresponding conclusions were drawn on leaders in volume among EAEU member countries. Top trends and problems of development of trade in services of member countries are revealed.
\end{abstract}

Keywords: Eurasian Economic Union; a single market of services; trade in services; economic integration; international trade

\section{Introduction}

On May 29, 2014, the Republic of Belarus, the Republic of Kazakhstan and the Russian Federation signed the Treaty on the Eurasian Economic Union, which entered into force on January 1, 2015 (Treaty on the EAEU). Since January 2, 2015, the Republic of Armenia joined the Treaty on the EAEU (Treaty on the Accession of the Republic of Armenia to the Treaty on the Eurasian Economic Union, 2014), from August 12, 2015 - the Kyrgyz Republic (Treaty on the Accession of the Kyrgyz Republic to the Treaty on the Eurasian Economic Union, 2014). The EAEU Treaty was the result of two years of codification of international treaties within the framework of a single economic space.

The Treaty on the EAEU established the Eurasian Economic Union (EAEU) as an international organization of regional economic integration with international legal personality. One of the main objectives of the EAEU is the desire to create a single market for goods, services, capital, and labor within the union. 
According to the Treaty on the EAEU, the "EAEU Single Market of Services" (Legal portal of the Eurasian Economic Union, 2011) is understood as a market situation of services within the specific sector in which each state member grants to persons of any other state member the right on:

1) supply and receipt of services without any restrictions, exceptions and additional requirements;

2) supply of services without an additional institution in the form of a legal entity;

3) supply of services based on a permit for the supply of services received by a service provider in the territory of its Member State;

4) recognition of the professional qualifications of the personnel of the service supplier.

Today, the EAEU has been operating since January 1, 2015, EAEU Single Market of Services has been created in 52 sectors, and therefore, the analysis of trade in services (external and internal) of the EAEU member states presented in this article that could show whether efforts to create a single EAEU services market have a practical impact on increasing internal trade in services.

\section{Literature review}

Within the functioning of the WTO, it should be noted the general agreement on trade in services (further - the Agreement; became effective in January 1995) representing the body of principles and rules of trade in services. The purpose of this Agreement is the creation of a multilateral system of the principles and rules of trade in services for the expansion of such trade on the terms of transparency and purchasing liberalization and as means of assistance to the economic growth of all trading partners, to development of developing countries. The scope of the Agreement extends to the measures of the countries of the WTO affecting trade in services (Legal portal of The World Trade Organization, 1995).

Trade in services within the Eurasian Economic Union is not highlighted in publications of domestic and foreign authors not often. However, this fact does not reduce the importance and relevance of this subject and allows completing studying this problem. One of the innovators in the question of trade in services in the Eurasian Economic Union is A. Zhurova with the work "Trade in services in the Eurasian Economic Union. The education guidance" (Zhurova, 2016) in which questions of the service industry liberalization, features of regulation of international trade in services within the WTO, trade in services in the European Union, NAFTA, MERCOSUR are considered. Special attention is paid to the creation of the domestic market of EAEU.

\section{The methodology of the study}

During the research, EAEU and member countries' legal acts were used, as well as comparative, analytical, statistical, descriptive, historical, systematic research methods. 


\section{Results}

The Supreme Eurasian Economic Council approves the single market of services within the union and today consists of 52 sectors (Information and legal system of regulatory legal acts..., 2014) that by different calculations is estimated at $50-55 \%$ of all sectors of services.

The author considered the dynamics of foreign trade in services of EAEU member states with third countries and the dynamics of internal trade in services between EAEU member states during the period of the EAEU functioning.

Concerning foreign trade in services, Article 38 of the EAEU Treaty establishes that the Member States shall coordinate trade in services with third parties, while this coordination, however, shall not imply any supranational jurisdiction of the union in this sphere.

Thus, we can say that foreign trade in services has been preserved in the national competence of member states. In particular, an example of this is the dissemination of section 8 "Trade in services, investments, and movement of persons" of the Free Trade Agreement between the Eurasian Economic Union and its member states, on the one hand, and the Socialist Republic of Vietnam, on the other hand, only to the Russian Federation and Vietnam (Legal portal of the Eurasian Economic Union, 2015). To assess the potential of foreign trade in services of EAEU countries, we consider the dynamics of trade in services of EAEU member states with third countries in 2015-2018 (Table 1).

Table 1

\section{Dynamics of trade in services of EAEU member states with third countries, 2015-2017, million dollars}

\begin{tabular}{|c|c|c|c|c|}
\hline Indicator & 2015 & 2016 & 2017 & $\begin{array}{c}\text { Growth (decrease) } \\
2017 \text { to } 2015, \%\end{array}$ \\
\hline \multicolumn{5}{|l|}{ Export of services } \\
\hline Republic of Armenia & - & - & - & - \\
\hline Republic of Belarus & 4845.30 & 5086.80 & 5604.70 & $15.7 \%$ \\
\hline Republic of Kazakhstan & 4284.70 & 4529.90 & 4653.30 & $8.6 \%$ \\
\hline The Kyrgyz Republic* & - & 325.60 & 294.10 & - \\
\hline Russian Federation & 32836.80 & 47016.40 & 53501.90 & $62.9 \%$ \\
\hline EAEU** & 41966.80 & 56958.70 & 64054.00 & $52.6 \%$ \\
\hline \multicolumn{5}{|l|}{ Import of services } \\
\hline Republic of Armenia & - & - & - & - \\
\hline Republic of Belarus & 3109.7 & 3123.9 & 3234.9 & $4.0 \%$ \\
\hline Republic of Kazakhstan & 9441.3 & 9014.0 & 8541.5 & $-9.5 \%$ \\
\hline Kyrgyz Republic & н.д. & 522.6 & 428.2 & - \\
\hline Russian Federation & 85353.30 & 71476.50 & 85234.30 & $-0.1 \%$ \\
\hline EAEU & 97904.30 & 84137.00 & 97438.90 & $-0.5 \%$ \\
\hline
\end{tabular}


Table 1, ending

\begin{tabular}{lcccc}
\hline \multicolumn{1}{c}{ Indicator } & $\mathbf{2 0 1 5}$ & $\mathbf{2 0 1 6}$ & $\mathbf{2 0 1 7}$ & $\begin{array}{c}\text { Growth (decrease) } \\
\mathbf{2 0 1 7} \text { to 2015,\% }\end{array}$ \\
\hline Turnover of services & & & & - \\
Republic of Armenia & - & - & - & $11.1 \%$ \\
Republic of Belarus & 7955.00 & 8210.70 & 8839.60 & $-3.9 \%$ \\
Republic of Kazakhstan & 13726.00 & 13543.90 & 13194.80 & - \\
Kyrgyz Republic & - & 848.20 & 722.30 & $17.4 \%$ \\
Russian Federation & 118190.10 & 118492.90 & 138736.20 & $15.5 \%$ \\
EAEU & 139871.10 & 141095.70 & 161492.90 & \\
\hline
\end{tabular}
Armenia.

Note: * data for the Kyrgyz Republic are given since 2016; ${ }^{* \star}$ no data for the Republic of

Source: Eurasian Economic Commission. Export and import of services in the Eurasian Economic Union. 2017. Statistical Bulletin. http://www.eurasiancommission.org/en/act/integr i_makroec/dep_stat/fin_stat/statistical_publications/Pages/default.aspx (accessed: 14.07.2019).

Table 2 shows the share of trade in services with third countries in the aggregate trade indicators of the EAEU countries since the creation of integration.

Table 2

Share of trade in services with third countries in the total volume of trade in services of the EAEU countries, 2015-2017, \%

\begin{tabular}{|c|c|c|c|c|}
\hline Indicator & 2015 & 2016 & 2017 & Change of 2017 to 2015 , \% \\
\hline \multicolumn{5}{|l|}{ Export of services } \\
\hline Republic of Armenia & - & - & - & - \\
\hline Republic of Belarus & $73.1 \%$ & $74.5 \%$ & $71.5 \%$ & $-1.5 \%$ \\
\hline Republic of Kazakhstan & $66.2 \%$ & $71.8 \%$ & $72.3 \%$ & $6.1 \%$ \\
\hline The Kyrgyz Republic* & - & $38.7 \%$ & $35.7 \%$ & - \\
\hline Russian Federation & $88.2 \%$ & $92.8 \%$ & $92.7 \%$ & $4.4 \%$ \\
\hline EAEU** & $83.4 \%$ & $88.1 \%$ & $88.0 \%$ & $4.6 \%$ \\
\hline \multicolumn{5}{|l|}{ Import of services } \\
\hline Republic of Armenia & - & - & - & - \\
\hline Republic of Belarus & $70.8 \%$ & $71.9 \%$ & $67.4 \%$ & $-3.4 \%$ \\
\hline Republic of Kazakhstan & $81.5 \%$ & $81.5 \%$ & $78.7 \%$ & $-2.8 \%$ \\
\hline Kyrgyz Republic & - & $50.0 \%$ & $46.8 \%$ & - \\
\hline Russian Federation & $96.2 \%$ & $95.9 \%$ & $96.0 \%$ & $-0.2 \%$ \\
\hline EAEU & $93.5 \%$ & $92.4 \%$ & $92.5 \%$ & $-1.0 \%$ \\
\hline
\end{tabular}


Table 2, ending

Indicator

Turnover of services

Republic of Armenia

Republic of Belarus

Republic of Kazakhstan

Kyrgyz Republic

Russian Federation

EAEU
2015

2016

2017

Change of 2017 to 2015 , \% Armenia.

Note: * data for the Kyrgyz Republic are given since 2016; ${ }^{*}$ no data for the Republic of

Source: Eurasian Economic Commission. Export and import of services in the Eurasian Economic Union. 2017. Statistical Bulletin. http://www.eurasiancommission.org/en/act/integr_ i_makroec/dep_stat/fin_stat/statistical_publications/Pages/default.aspx (accessed: 14.07.2019).

Conclusions follow from the provided data:

1. Dynamics of trade in services with the third countries (foreign trade in services) of EAEU is specified:

- significant increase in export of services to the third countries (for $52.6 \%$ in 2017 in comparison with 2015) - generally due to growth of trade in services of Russia with the third countries (up for $62.9 \%$ ). At the same time, higher growth rates of trade with third countries as a whole are observed compared with trade between EAEU countries (Chernova et al., 2019);

- the volume of service import from the third countries decreased (by $0.5 \%$ in 2017 in comparison with 2015) - Kazakhstan made the main contribution to decreasing in the import of services from the third countries in EAEU - decrease in import of services in 2017 in comparison with 2015 was $9.5 \%$ or $899.8 \mathrm{mln}$ USD;

- prevailing trends in the dynamics of exports and imports determined the status of services turnover with third countries: it increased by $15.5 \%$ in 2017 compared to 2015. Negative dynamics of service turnover with third countries was typical only for Kazakhstan, with the turnover decreased by $3.9 \%$ in 2017 compared to 2015.

Trade in services with third countries should be considered as the main driver for internal trade in services in the EAEU as part of a single service market creation. So, under "ideal" conditions, a decrease in the turnover of services with third countries should be accompanied by an increase in internal trade in services volume, and vice versa. At the same time, it should be noted that the decline in imports could have occurred for many other reasons (not only in connection with the replacement of imports of services from third countries by internal trade in services): unstable rates of national currencies, lack of need for specific types of services, etc.

2. The second group of trends in trade in services with third countries was quantitatively reflected in Table 1, from which the following main conclusions can be drawn: 
- in the period under review, there was an increase in the share of services exports in the total volume of exports of services of EAEU countries to third countries by $4.6 \%$. Trade in services of the Kyrgyz Republic, which acceded to the Agreement on August 12, 2015, is characterized by the smallest share of export of services to third countries, 2.5 times lower than the average share of export of services to third countries in the EAEU (35.7\% in 2017 in the Kyrgyz Republic compared with $88 \%$ in the EAEU as a whole). Thus, even at the time of the creation of the EAEU, trade in services of individual countries in terms of their exports was characterized by a low level of involvement in economic relations with third countries and, accordingly, significant prerequisites for creating an internal services market (Eurasian Economic Commission, 2018-2019);

- a significant share of imports of services from third countries to the EAEU (92.5\% in 2017) was formed mainly due to the contribution of imports of Russian services from third countries ( $96 \%$ in 2017). Thus, this is another confirmation that the main intra-territorial segment of the single services market and the source of its development in terms of their imports is Russia (Andronova, 2016);

- in 2017, there was a slight increase in the share of services turnover in third countries (by $0.4 \%$ compared to 2015 ). In a situation where $85.9 \%$ (in 2017) of trade in services with third countries falls on Russia, the further development of the foreign trade in services of the EAEU will be determined by the trends in this state.

Consider some indicators of internal trade in services in the EAEU since the creation of the union (Table 3 ).

Internal trade in services of EAEU member states, 2015-2017

\begin{tabular}{lccc}
\hline \multicolumn{1}{c}{ Indicator } & $\mathbf{2 0 1 5}$ & $\mathbf{2 0 1 6}$ & $\mathbf{2 0 1 7}$ \\
\hline Export of services & & & \\
Republic of Armenia & - & - & - \\
Republic of Belarus & 1786.10 & 1740.20 & 2229.60 \\
Republic of Kazakhstan & 2191.20 & 1777.10 & 1785.60 \\
The Kyrgyz Republic & - & 515.50 & 529.60 \\
Russian Federation & 4379.10 & 3660.80 & 4227.90 \\
EAEU ** & 8356.40 & 7693.60 & 8772.70 \\
Import of services & & & \\
Republic of Armenia & - & - & - \\
Republic of Belarus & 1280.0 & 1223.3 & 1563.0 \\
Republic of Kazakhstan & 2141.0 & 2048.8 & 2316.3 \\
Kyrgyz Republic & - & 521.9 & 487.6 \\
Russian Federation & 3414.70 & 3090.50 & 3590.20 \\
EAEU & 6835.70 & 6884.50 & 7957.10 \\
\hline
\end{tabular}


Table 3, ending

\begin{tabular}{lccc}
\hline \multicolumn{1}{c}{ Indicator } & $\mathbf{2 0 1 5}$ & $\mathbf{2 0 1 6}$ & $\mathbf{2 0 1 7}$ \\
\hline Turnover of services & - & & \\
Republic of Armenia & 3066.10 & 2963.50 & 3792.60 \\
Republic of Belarus & 4332.20 & 3825.90 & 4101.90 \\
Republic of Kazakhstan & - & 1037.40 & 1017.20 \\
Kyrgyz Republic & 7793.80 & 6751.30 & 7818.10 \\
Russian Federation & 15192.10 & 14578.10 & 16729.80 \\
EAEU & &
\end{tabular}

Note: * data for the Kyrgyz Republic are given since 2016; ${ }^{*}$ no data for the Republic of Armenia.

Source: Eurasian Economic Commission. Export and import of services in the Eurasian Economic Union. 2017. Statistical Bulletin. http://www.eurasiancommission.org/en/act/integr_ i_makroec/dep_stat/fin_stat/statistical_publications/Pages/default.aspx (accessed: 14.07.2019).

In the structure of internal trade, the bulk of cross-border mutual payments for services rendered falls to the most powerful economies - the Russian Federation and the Republic of Kazakhstan. Although the previous is quite natural, we note that a decrease in the aggregate share of these countries in mutual trade is definite (Figure 1). Thus, there is a geographical diversification of trade in services, a decrease in the dependence of the state of the single service market on a narrow group of countries.

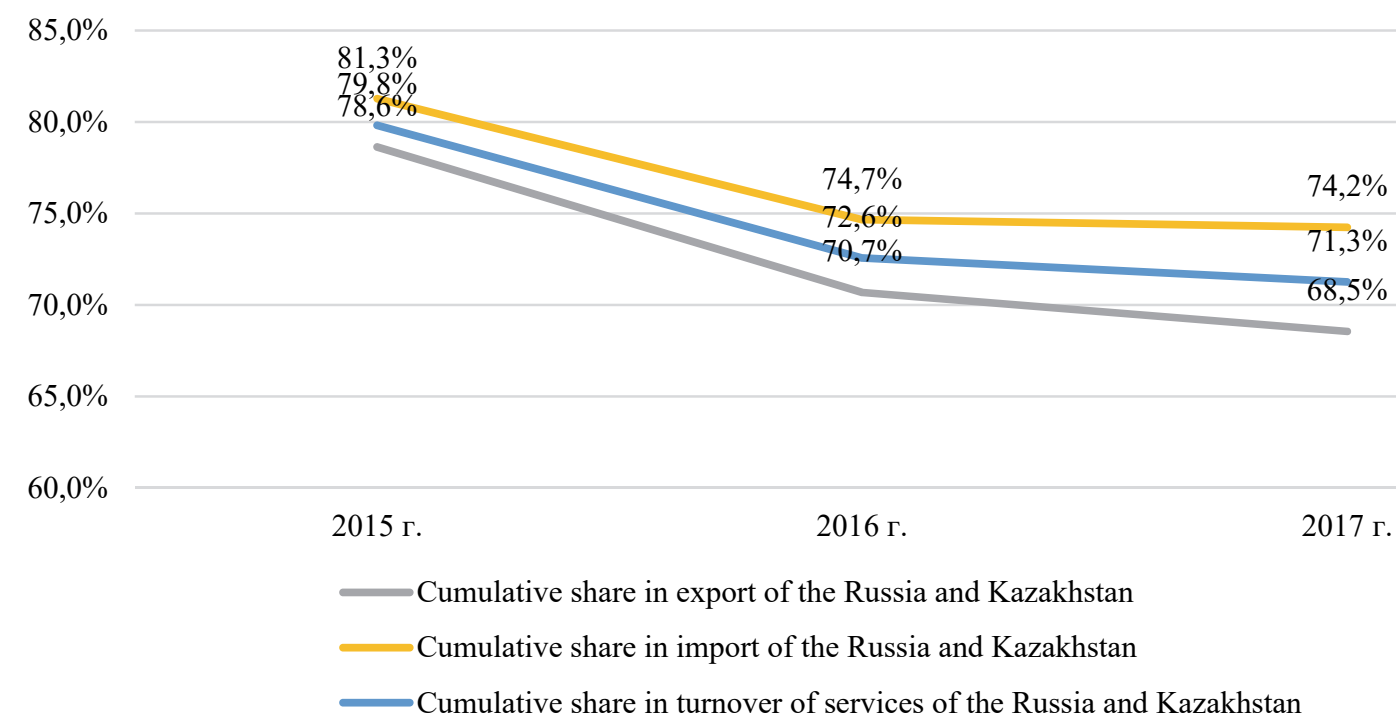

Figure 1. The share of the largest economies of the EAEU (the Russian Federation and the Republic of Kazakhstan) in the structure of internal trade in services (the ratio of internal trade in services in two countries to the total volume of internal trade in services in the EAEU), 2015-2017, \%

Source: Eurasian Economic Commission. Export and import of services in the Eurasian Economic Union. 2017. Statistical Bulletin. http://www.eurasiancommission.org/en/act/integr_ i_makroec/dep_stat/fin_stat/statistical_publications/Pages/default.aspx (accessed: 14.07.2019). 
Table 4 shows the data characterizing the share of internal trade in EAEU services in the total trade turnover of integration since its inception.

Table 4

\section{The share of internal trade in services of EAEU countries in the total integration turnover, 2015-2017, \%}

\begin{tabular}{|c|c|c|c|c|}
\hline Indicator & 2015 & 2016 & 2017 & Change of 2017 to $2015, \%$ \\
\hline \multicolumn{5}{|l|}{ Export of services } \\
\hline Republic of Armenia & - & - & - & - \\
\hline Republic of Belarus & $26.9 \%$ & $25.5 \%$ & $28.5 \%$ & $1.5 \%$ \\
\hline Republic of Kazakhstan & $33.8 \%$ & $28.2 \%$ & $27.7 \%$ & $-6.1 \%$ \\
\hline The Kyrgyz Republic* & - & $61.3 \%$ & $64.3 \%$ & - \\
\hline Russian Federation & $11.8 \%$ & $7.2 \%$ & $7.3 \%$ & $-4.4 \%$ \\
\hline EAEU ** & $16.6 \%$ & $11.9 \%$ & $12.0 \%$ & $-4.6 \%$ \\
\hline \multicolumn{5}{|l|}{ Import of services } \\
\hline Republic of Armenia & - & - & - & - \\
\hline Republic of Belarus & $29.2 \%$ & $28.1 \%$ & $32.6 \%$ & $3.4 \%$ \\
\hline Republic of Kazakhstan & $18.5 \%$ & $18.5 \%$ & $21.3 \%$ & $2.8 \%$ \\
\hline Kyrgyz Republic & - & $50.0 \%$ & $53.2 \%$ & - \\
\hline Russian Federation & $3.8 \%$ & $4.1 \%$ & $4.0 \%$ & $0.2 \%$ \\
\hline EAEU & $6.5 \%$ & $7.6 \%$ & $7.5 \%$ & $1.0 \%$ \\
\hline \multicolumn{5}{|l|}{ Turnover of services } \\
\hline Republic of Armenia & - & - & - & - \\
\hline Republic of Belarus & $27.8 \%$ & $26.5 \%$ & $30.0 \%$ & $2.2 \%$ \\
\hline Republic of Kazakhstan & $24.0 \%$ & $22.0 \%$ & $23.7 \%$ & $-0.3 \%$ \\
\hline Kyrgyz Republic & - & $55.0 \%$ & $58.5 \%$ & - \\
\hline Russian Federation & $6.2 \%$ & $5.4 \%$ & $5.3 \%$ & $-0.9 \%$ \\
\hline EAEU & $9.8 \%$ & $9.4 \%$ & $9.4 \%$ & $-0.4 \%$ \\
\hline
\end{tabular}

Note:* data for the Kyrgyz Republic are given since 2016; ${ }^{* \star}$ no data for the Republic of Armenia.

Source: Eurasian Economic Commission. Export and import of services in the Eurasian Economic Union. 2017. Statistical Bulletin. http://www.eurasiancommission.org/en/act/integr i_makroec/dep_stat/fin_stat/statistical_publications/Pages/default.aspx (accessed: 14.07.2019).

Conclusions that indirectly characterize the efficiency of measures for the formation of the uniform market of services of EAEU follow from the data provided in Table 4. The emerging trends are "symmetrical" to the trends prevailing in trade in services with third countries. So, a decrease in the share of internal ex- 
port of services from $16.6 \%$ in 2015 up to $12 \%$ in 2017 in the cumulative export of services of the countries of EAEU is observed. The largest economies made the most significant contribution to decrease in a share of internal export of services of EAEU: in Russia decreased in the called indicator in 2017 in comparison with 2015 was $4.4 \%$, in Kazakhstan $-6.1 \%$. We believe, in this regard, that even provided that four rather small economies of EAEU cannot make full foreign market of sale of services for the Russian economy, low share of internal export of Russia in EAEU (7.3\% in 2017) is in many respects caused by the existing barriers of creation of the uniform market of services (Functioning of domestic market..., 2017).

Besides, the EAEU member states fixed the Individual national lists of restrictions, exceptions, additional requirements, and conditions Decision of the Supreme Eurasian Economic Council No. 112, 2014): for the Republic of Kazakhstan - 30; for the Republic of Belarus - 28; for the Russian Federation - 38; for the Republic of Armenia - 9; for the Kyrgyz Republic - 13.

Undoubtedly, many of these restrictions are a significant reason for the current situation in trade in services within the EAEU.

Regarding integration import of services to EAEU, the positive dynamics connected with an increase in its share in the aggregate turnover of the countries of EAEU by 1\% in 2017 in comparison with 2015 is observed. We will note heterogeneity in structure of internal import of services in the countries of EAEU (Figure 2) that is predetermined not only by the sizes of the corresponding economy, but also a condition of implementation of measures for elimination of barriers of development of internal trade in services and formations of the uniform market of services.

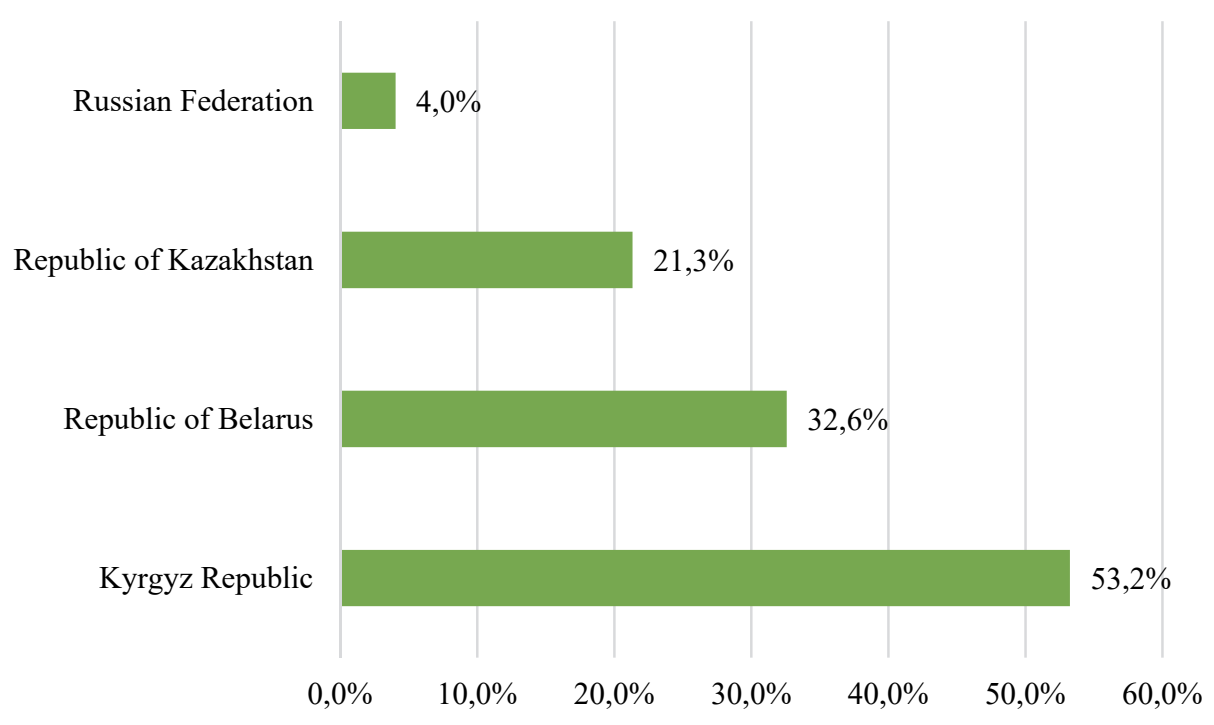

Figure 2. Share of internal imports of services (ratio of internal trade in services to total internal and foreign trade in services) by EAEU countries, 2017

Source: Eurasian Economic Commission. Export and import of services in the Eurasian Economic Union. 2017. Statistical Bulletin. http://www.eurasiancommission.org/en/act/integr i_makroec/dep_stat/fin_stat/statistical_publications/Pages/default.aspx (accessed: 14.07.2019). 
Analyzing the reasons for the developing trends, we will pay attention also to the industry structure of internal trade in services for the considered period. In the structure of internal trade in services of EAEU by their types of transport services, trips, and other business services (Table 5) prevail.

Table 5

Internal trade in services in the EAEU by type, 2015-2017, million dollars*

\begin{tabular}{|c|c|c|c|}
\hline Indicator & 2015 & 2016 & 2017 \\
\hline \multicolumn{4}{|l|}{ Export } \\
\hline Other material processing services & 189.6 & 218.6 & 280.3 \\
\hline Maintenance and Repair & 321.6 & 272.8 & 406.2 \\
\hline Transport services & 2324.2 & 2072.4 & 2203.3 \\
\hline Trips & 6462.0 & 21697.5 & 24804.1 \\
\hline Construction services & 694.9 & 615.0 & 1037.0 \\
\hline Insurance and services of private pension funds & 34.1 & 33.9 & 44.2 \\
\hline Financial services & 150.7 & 153.7 & 140.6 \\
\hline Intellectual Property Fee & 166.7 & 81.2 & 85.8 \\
\hline Telecommunication, computer and information services & 565.5 & 529.3 & 524.1 \\
\hline Other business services & 1010.0 & 922.1 & 951.0 \\
\hline $\begin{array}{l}\text { Services to individuals and services in the field of } \\
\text { culture and leisure }\end{array}$ & 46.6 & 54.7 & 84.1 \\
\hline Government goods and services not elsewhere classified & 29.9 & 33.3 & 21.2 \\
\hline Not distributed by service & 0.0 & 34.4 & 52.7 \\
\hline \multicolumn{4}{|l|}{ Import } \\
\hline Other material processing services & 151.1 & 223.9 & 292.1 \\
\hline Maintenance and Repair & 253.9 & 253.1 & 314.5 \\
\hline Transport services & 1566.4 & 1629.8 & 1974.4 \\
\hline Trips & 2359.4 & 2337.5 & 2248.5 \\
\hline Construction services & 708.8 & 740.0 & 1182.9 \\
\hline Insurance and services of private pension funds & 20.7 & 28.7 & 40.8 \\
\hline Financial services & 137.6 & 123.5 & 120.5 \\
\hline Intellectual Property Fee & 67.5 & 57.1 & 62.0 \\
\hline Telecommunication, computer and information services & 591.5 & 506.9 & 526.7 \\
\hline Other business services & 905.0 & 893.6 & 1065.0 \\
\hline $\begin{array}{l}\text { Services to individuals and services in the field of } \\
\text { culture and leisure }\end{array}$ & 51.8 & 49.1 & 84.2 \\
\hline Government goods and services not elsewhere classified & 22.0 & 22.7 & 24.7 \\
\hline Not distributed by service & 0.0 & 18.6 & 20.8 \\
\hline
\end{tabular}


Table 5, ending

\begin{tabular}{lccc}
\hline \multicolumn{1}{c}{ Indicator } & $\mathbf{2 0 1 5}$ & $\mathbf{2 0 1 6}$ & $\mathbf{2 0 1 7}$ \\
\hline Turnover & & & \\
Other material processing services & 540.7 & 442.5 & 572.4 \\
Maintenance and Repair & 3890.6 & 3702.2 & 4177.7 \\
Transport services & 5182.0 & 5009.7 & 5190.7 \\
Trips & 1403.7 & 1355.0 & 2219.9 \\
Construction services & 54.8 & 62.6 & 85.0 \\
Insurance and services of private pension funds & 288.3 & 277.2 & 261.1 \\
Financial services & 234.2 & 138.3 & 147.8 \\
Intellectual Property Fee & 1157.0 & 1036.2 & 1050.8 \\
Telecommunication, computer and information services & 1915.0 & 1815.7 & 2016.0 \\
Other business services & 98.4 & 103.8 & 168.3 \\
Services to individuals and services in the field of & 51.9 & 56.0 & 45.9 \\
culture and leisure & 0.0 & 87.2 & 97.6 \\
\hline Government goods and senvices not elsewhere classified & 51.9 & \\
Not distributed by service & & & \\
\hline
\end{tabular}

Note: data for the Kyrgyz Republic are given since 2016, no data for the Republic of Armenia.

Source: Eurasian Economic Commission. Export and import of services in the Eurasian Economic Union. 2017. Statistical Bulletin. http://www.eurasiancommission.org/en/act/integr i_makroec/dep_stat/fin_stat/statistical_publications/Pages/default.aspx (accessed: 14.07.2019).

Table 6

\section{The share of internal trade in services of EAEU countries by type in the total integration turnover, 2015-2017, \%}

\begin{tabular}{lccc}
\hline \multicolumn{1}{c}{ Indicator } & $\mathbf{2 0 1 5}$ & $\mathbf{2 0 1 6}$ & $\mathbf{2 0 1 7}$ \\
\hline Export & & & \\
Total & $\mathbf{1 6 . 6 \%}$ & $\mathbf{1 1 . 9 \%}$ & $\mathbf{1 2 . 0 \%}$ \\
Other material processing services & $16.1 \%$ & $12.4 \%$ & $16.4 \%$ \\
Maintenance and Repair & $17.8 \%$ & $15.2 \%$ & $18.7 \%$ \\
Transport services & $26.5 \%$ & $8.7 \%$ & $8.2 \%$ \\
Trips & $26.4 \%$ & $25.5 \%$ & $24.6 \%$ \\
Construction services & $13.8 \%$ & $12.4 \%$ & $17.6 \%$ \\
Insurance and services of private pension funds & $4.8 \%$ & $7.4 \%$ & $10.1 \%$ \\
Financial services & $12.0 \%$ & $12.5 \%$ & $11.7 \%$ \\
Intellectual Property Fee & $22.2 \%$ & $14.0 \%$ & $11.2 \%$ \\
Telecommunication, computer and information services & $11.1 \%$ & $10.1 \%$ & $8.4 \%$ \\
Other business services & $7.4 \%$ & $7.2 \%$ & $7.0 \%$ \\
Services to individuals and services in the field of culture & $13.2 \%$ & $12.6 \%$ & $16.5 \%$ \\
and leisure & $2.7 \%$ & $3.1 \%$ & $1.8 \%$ \\
Government goods and services not elsewhere classified & $2.0 \%$ & $57.5 \%$ & $67.3 \%$ \\
\hline Not distributed by service & & & \\
\hline
\end{tabular}


Table 6, ending

\begin{tabular}{|c|c|c|c|}
\hline Indicator & 2015 & 2016 & 2017 \\
\hline \multicolumn{4}{|l|}{ Import } \\
\hline Total & $6.5 \%$ & $7.6 \%$ & $7.5 \%$ \\
\hline Other material processing services & $75.3 \%$ & $83.4 \%$ & $90.5 \%$ \\
\hline Maintenance and Repair & $14.7 \%$ & $13.1 \%$ & $14.0 \%$ \\
\hline Transport services & $10.4 \%$ & $10.9 \%$ & $10.9 \%$ \\
\hline Trips & $6.2 \%$ & $8.7 \%$ & $6.6 \%$ \\
\hline Construction services & $9.4 \%$ & $10.8 \%$ & $16.6 \%$ \\
\hline Insurance and services of private pension funds & $1.4 \%$ & $2.7 \%$ & $3.1 \%$ \\
\hline Financial services & $5.7 \%$ & $4.6 \%$ & $4.4 \%$ \\
\hline Intellectual Property Fee & $1.1 \%$ & $1.1 \%$ & $1.0 \%$ \\
\hline Telecommunication, computer and information services & $9.7 \%$ & $8.4 \%$ & $8.9 \%$ \\
\hline Other business services & $3.8 \%$ & $4.0 \%$ & $4.4 \%$ \\
\hline $\begin{array}{l}\text { Services to individuals and services in the field of culture } \\
\text { and leisure }\end{array}$ & $4.4 \%$ & $4.4 \%$ & $5.4 \%$ \\
\hline Government goods and services not elsewhere classified & $1.3 \%$ & $1.3 \%$ & $1.6 \%$ \\
\hline Not distributed by service & $0.0 \%$ & $23.1 \%$ & $22.4 \%$ \\
\hline \multicolumn{4}{|l|}{ Turnover } \\
\hline Total & $9.8 \%$ & $9.4 \%$ & $9.4 \%$ \\
\hline Other material processing services & $24.7 \%$ & $21.9 \%$ & $28.1 \%$ \\
\hline Maintenance and Repair & $16.3 \%$ & $14.1 \%$ & $16.3 \%$ \\
\hline Transport services & $16.3 \%$ & $9.6 \%$ & $9.3 \%$ \\
\hline Trips & $10.7 \%$ & $13.4 \%$ & $11.3 \%$ \\
\hline Construction services & $11.2 \%$ & $11.5 \%$ & $17.0 \%$ \\
\hline Insurance and services of private pension funds & $2.5 \%$ & $4.2 \%$ & $4.9 \%$ \\
\hline Financial services & $7.9 \%$ & $7.1 \%$ & $6.6 \%$ \\
\hline Intellectual Property Fee & $3.5 \%$ & $2.4 \%$ & $2.1 \%$ \\
\hline Telecommunication, computer and information services & $10.3 \%$ & $9.2 \%$ & $8.6 \%$ \\
\hline Other business services & $5.2 \%$ & $5.2 \%$ & $5.3 \%$ \\
\hline $\begin{array}{l}\text { Services to individuals and services in the field of culture } \\
\text { and leisure }\end{array}$ & $6.4 \%$ & $6.7 \%$ & $8.2 \%$ \\
\hline Government goods and services not elsewhere classified & $1.8 \%$ & $2.0 \%$ & $1.7 \%$ \\
\hline Not distributed by service & $0.0 \%$ & $37.8 \%$ & $43.0 \%$ \\
\hline
\end{tabular}

Note: data for the Kyrgyz Republic are given since 2016, no data for the Republic of Armenia.

Source: Eurasian Economic Commission. Export and import of services in the Eurasian Economic Union. 2017. Statistical Bulletin. http://www.eurasiancommission.org/en/act/integr_ i_makroec/dep_stat/fin_stat/statistical_publications/Pages/default.aspx (accessed July 14, 2019).

The share of each type of service in their total turnover is given in Table 6 .

Apparently, most of the countries of EAEU succeeded in internal trade in services in such industries as services in processing of the material resources belonging to other parties $(28.1 \%$ of internal trade in the total turnover of services for 2017), construction services (17\% in 2017), technical maintenance and repair (16.3\% in 2017), trips (11.3\%). The other industries of services are characterized by values below $10 \%$ or instability during the functioning of EAEU. The revealed trends can characterize insufficient efficiency of the measures for forming the uni- 
form market of services of the countries of EAEU undertaken in current conditions. This once again confirms that the main objective is to strengthen economic ties between the EAEU countries through the creation of common economic interests. Thus, by results of the carried-out analysis of a condition of the uniform market of services of the countries of EAEU from the moment of creation of this integration consolidation, trends which characterize the measures for forming of the uniform market of services undertaken by the countries as insufficiently active and demanding further improvement as the chosen course of development of the uniform market of services, and concrete measures for its forming were observed (Gusakov, Andronova, 2015).

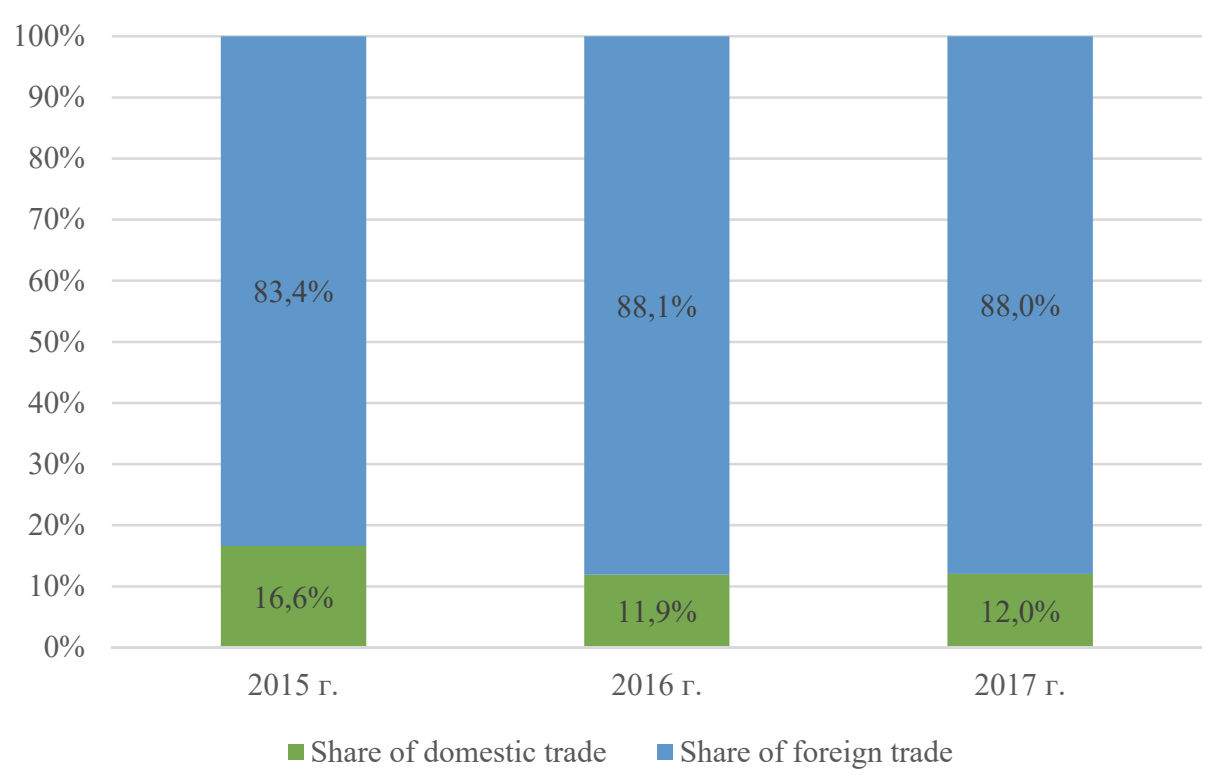

Figure 3. The ratio of the share of foreign and internal trade in services in the EAEU countries in terms of their exports, 2015-2017, \%

Note: data for the Kyrgyz Republic are given since 2016, no data for the Republic of Armenia.

Source: Eurasian Economic Commission. Export and import of services in the Eurasian Economic Union. 2017. Statistical Bulletin. http://www.eurasiancommission.org/en/act/integr_ i_makroec/dep_stat/fin_stat/statistical_publications/Pages/default.aspx (accessed: 14.07.2019).

For the analyzed period (from the moment of creation of EAEU), there was a decrease in a share of internal trade in services (their turnover - as the amounts of export and import of services) up to $9.4 \%$ in 2017 (in comparison with $9.8 \%$ in 2015). The lack of the full-fledged statistical base of particular countries of EAEU attracts attention that complicates the development of concrete measures for the development of the uniform market of services. For example, in the official generalized statistics of the countries of EAEU, there are no data on trade in services of the Republic of Armenia. Data of the Central Bank of a said country also do not give a picture of trade in services with the EAEU countries. In cost values increase in the volume of internal trade in services regarding their turnover at 1.5 bln USD in 2017, in comparison with 2015, is observed. The decrease in 
a share of internal trade in services regarding their turnover is caused by high rates of a gain of trade in services with the third countries. Thus, it is possible to say that there is a gradual replacement of internal trade in services external that can be represented visually in a schedule type (Figures 3-5).

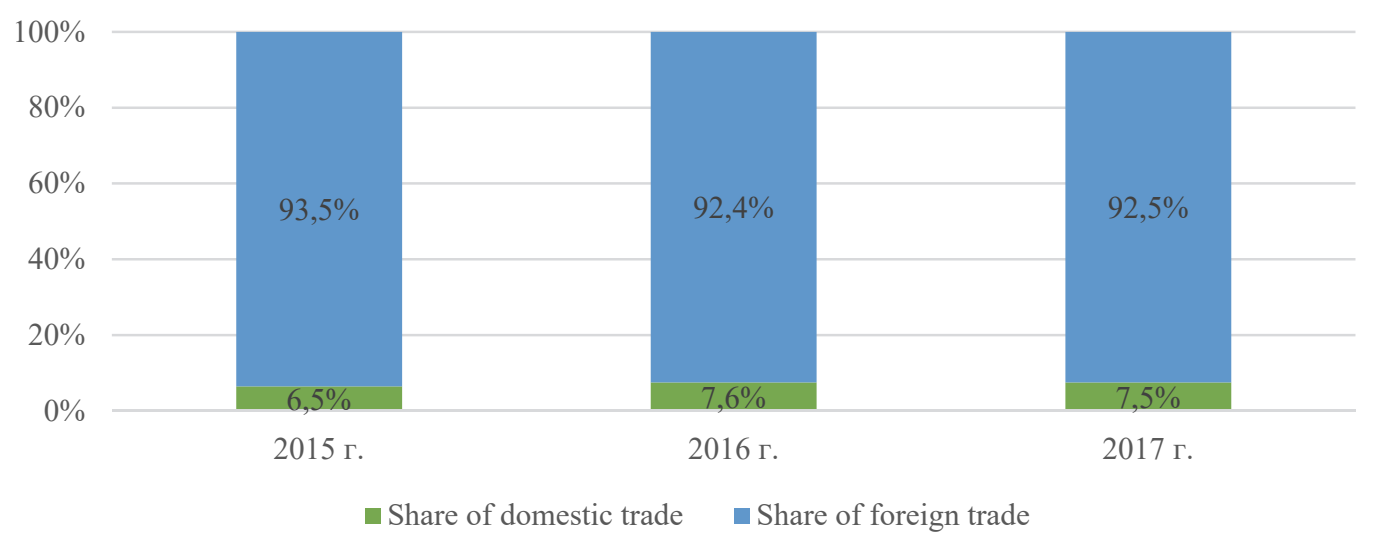

Figure 4. The ratio of the share of foreign and internal trade in services in the EAEU countries in terms of their imports, 2015-2017, \%

Note: data for the Kyrgyz Republic are given since 2016, no data for the Republic of Armenia.

Source: Eurasian Economic Commission. Export and import of services in the Eurasian Economic Union. 2017. Statistical Bulletin. http://www.eurasiancommission.org/en/act/integr_ i_makroec/dep_stat/fin_stat/statistical_publications/Pages/default.aspx (accessed: 14.07.2019).

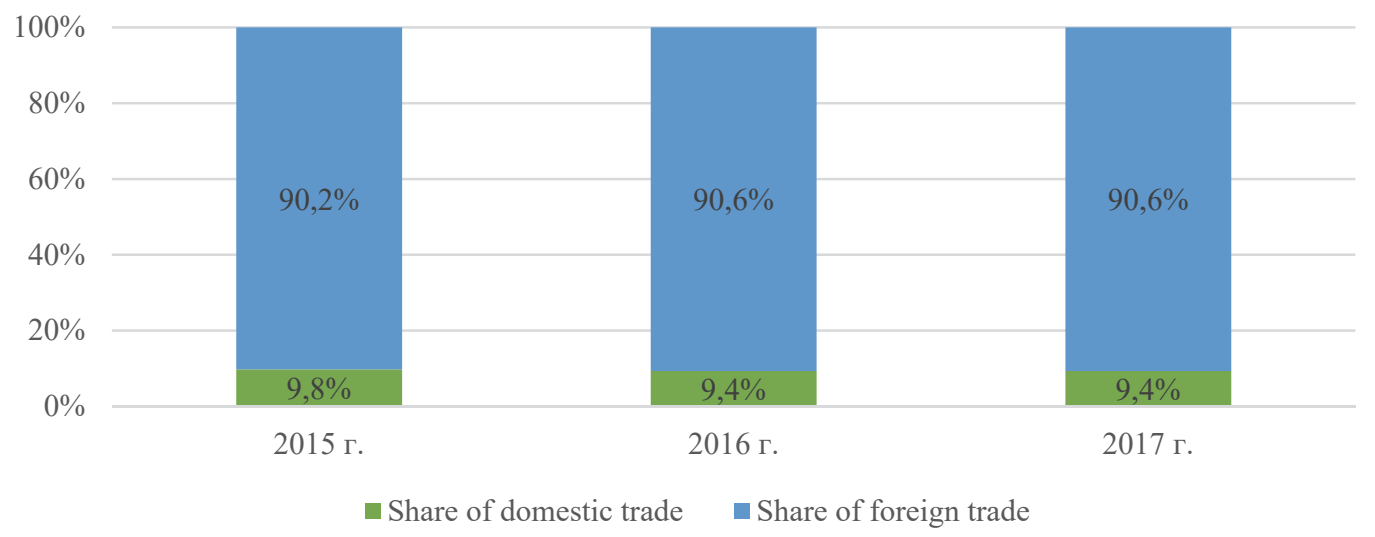

Figure 5. The ratio of the share of foreign and internal trade in services in the EAEU countries in terms of their turnover, 2015-2017, \%

Note: data for the Kyrgyz Republic are given since 2016, no data for the Republic of Armenia.

Source: Eurasian Economic Commission. Export and import of services in the Eurasian Economic Union. 2017. Statistical Bulletin. http://www.eurasiancommission.org/en/act/integr_ i_makroec/dep_stat/fin_stat/statistical_publications/Pages/default.aspx (accessed: 14.07.2019).

\section{Conclusion}

Problems of forming the uniform market of services in the territory of EAEU are shown especially visually shown in the analysis of trends by the specific countries and the industries of services that were shown earlier in the industry and re- 
gional analysis of forming of the uniform market of services of integration. The particular countries, first of all, the leading economies of EAEU, which form the main potential of development of the uniform market of services, are allocated.

Today EAEU member countries not fully managed to overcome regulatory requirements and procedures in the market of the union that interferes with further market development of services. Within functioning of the uniform market of services in the territory of the countries of EAEU conditions for providing the free movement of services, diversification of business in the service industry have to be created, new types of business in the territory of the EAEU partner countries are created, additional investments into economies of the countries of EAEU at the expense of the direction of internal cash flows are involved.

\section{References}

Andronova I. (2016). Eurasian Economic Union: Opportunities and Barriers to Regional and Global Leadership. Bulletin of International Organizations: Education, Science, New Economy, 11(2), 7-23. (In Russ.)

Chernova V.Y., Degtereva E.A., Zobov A.M., Andronova I.V., Starostin V.S. (2019). Integration processes in the Eurasian Economic Union (EAEU): The influence of macroeconomic and political factors. Espacios, 40(16), 8-14.

Eurasian Economic Commission. (2017). Export and import of services in the Eurasian Economic Union. Statistical Bulletin. http://www.eurasiancommission.org/en/act/integr_i_ makroec/dep_stat/fin_stat/statistical_publications/Pages/default.aspx (accessed: 14.07.2019).

Eurasian Economic Commission. (2018-2019). Report on the results of the implementation of the Basic Guidelines for Macroeconomic Policy of the Member States of the Eurasian Economic Union for 2018-2019. http://www.eurasiancommission.org/ru/act/integr_i makroec/dep_makroec_pol/ConsultKomitet/Documents/\%d0\%9e $\% \mathrm{~d} 1 \% 82 \% \mathrm{~d} 1 \% 87 \%$ d0\%b5\%d1\%82_2019.pdf (accessed: 08.10.2019).

Functioning of domestic market: Portal of general information resources and open data. (2017). The Report "On the work to identify and remove barriers, exemptions and restrictions on the domestic market of the Eurasian Economic Union for 2017". https://barriers. eaeunion.org/ru-ru/Pages/documents.aspx (accessed: 08.10.2019).

Gusakov N.P., Andronova I.V. (2015). Prospects for the development of the Eurasian Economic Union in the context of foreign economic security of the Russian Federation. Bulletin of the Peoples' Friendship University of Russia. Series: Economics, (1), 47-56. (In Russ.)

Information and legal system of regulatory legal acts of the Republic of Kazakhstan. (2014). Decision of the Supreme Eurasian Economic Council dated December 23, 2014 No. 110 "On approval of the list of sectors (subsectors) of services in which the single market for services operates within the Eurasian Economic Union". http://adilet.zan.kz/rus/docs/ H14B0000110 (accessed: 04.08.2019).

Legal portal of the Eurasian Economic Union. (2011). Protocol on trade in services, institutions, activities, and investments (Appendix No. 16 to the Treaty on the Eurasian Economic Union). http://docs.eaeunion.org/docs/ru-ru/0043610/itia_05062014 (accessed: 04.08.2019).

Legal portal of the Eurasian Economic Union. (2015). The Free Trade Agreement between the Eurasian Economic Union and its member states, on the one hand, and the Socialist Republic of Vietnam, on the other hand, dated May 29, 2015. http://docs.eaeunion.org/ docs/ru-ru/0127918/iatc_02062015 (accessed: 04.08.2019).

Legal portal of the Eurasian Economic Union. Treaty on the Accession of the Republic of Armenia to the Treaty on the Eurasian Economic Union of May 29, 2014. http://docs. eaeunion.org/docs/ru-ru/0047297/itia_11102014 (accessed: 04.08.2019). 
Legal portal of the Eurasian Economic Union. Treaty on the Accession of the Kyrgyz Republic to the Treaty on the Eurasian Economic Union of May 29, 2014. http://docs.eaeunion.org/ docs/ru-ru/0147066/itia 26122014 (accessed: 04.08.2019).

Legal portal of the Eurasian Economic Union. Treaty on the Eurasian Economic Union. $\mathrm{http}: / /$ docs.eaeunion.org/docs/ru-ru/0043610/itia_05062014 (accessed: 04.08.2019).

Legal portal of The World Trade Organization (WTO). (1995). General Agreement on Trade in Services (GATS). https://www.wto.org/english/docs_e/legal_e/26-gats.pdf (accessed: 08.10.2019).

Zhurova A.V. (2016). Torgovlya uslugami v Yevraziyskom ekonomicheskom soyuze [Trade in Services in the Eurasian Economic Union]: tutorial. Moscow: Prospect Publ. (In Russ.).

\title{
Article history:
}

Received: 04.08.2019

Revised: 07.09.2019

Accepted: 15.10.2019

\section{For citation:}

Yelikbaev K.N. (2019). Trade in services of member states of the Eurasian Economic Union. RUDN Journal of Economics, 27(3), 587-603. http://dx.doi.org/10.22363/23132329-2019-27-3-587-603

\section{Bio note:}

Kuanysh N. Yelikbayev, Deputy Director of Internal Markets Operation Department, Eurasian Economic Commission. E-mail: kuan1@mail.ru

\section{Торговля услугами в странах Евразийского экономического союза}

\author{
К.Н. Еликбаев \\ Евразийская экономическая комиссия \\ Российская Федеращия, 119121, Москва, Смоленский бульвар, д. 3/5, стр. 1
}

Договор о Евразийском экономическом союзе, вступивший в силу 1 января 2015 г., устанавливает принципы и цели интеграции, особенности взаимодействия между странами - участницами союза, а также обеспечивает свободное движение товаров, услуг, капитала и рабочей силы внутри союза. В статье дан анализ внешней и внутренней торговли услугами в Евразийском экономическом союзе. Рассмотрены структура, объемы импорта и экспорта стран - членов ЕАЭС. Актуальность темы связана с тем, что свободное движение услуг является одним из основных направлений интеграции в рамках Евразийского экономического союза. В результате проведенного исследования выявлены лидеры по объему торговли услугами среди стран - членов ЕАЭС, а также основные тенденции и проблемы, затрудняющие развитие торговли услугами.

Ключевые слова: Евразийский экономический союз; единый рынок услуг; торговля услугами; экономическая интеграция; международная торговля 


\section{История статьи:}

Дата поступления в редакцию: 04.08.2019

Дата проверки: 07.09.2019

Дата принятия к печати: 15.09.2019

\section{Для цитирования:}

Yelikbaev K.N. Trade in services of member states of the Eurasian Economic Union (Торговля услугами в странах Евразийского экономического союза) // Вестник Российского университета дружбы народов. Серия: Экономика. 2019. Т. 27. № 3. С. 587-603. http://dx.doi.org/10.22363/2313-2329-2019-27-3-587-603

\section{Сведения об авторе:}

Еликбаев Куаныли Нурланович, заместитель директора департамента функционирования внутренних рынков, Евразийская экономическая комиссия. E-mail: kuan1@mail.ru 